\title{
PENGOLAHAN LIMBAH Cr(VI) DAN FENOL DENGAN FOTOKATALIS SERBUK $\mathrm{TiO}_{2}$ DAN CuO/TiO ${ }_{2}$
}

\author{
Slamet, R. Arbianti dan E. Marliana*)
}

\begin{abstract}
Abstrak
Studi tentang pengolahan limbah $\mathrm{Cr}(\mathrm{VI})$ dan fenol secara fotokatalisis telah dilakukan dengan fotokatalis $\mathrm{TiO}_{2}$ dan $\mathrm{CuO} / \mathrm{TiO}_{2}$. Katalis $\mathrm{CuO} / \mathrm{TiO} \mathrm{O}_{2}$ dipreparasi dengan cara impregnasi terhadap $\mathrm{TiO}_{2}$ Degussa P25 menggunakan larutan garam tembaga yang berasal dari berbagai jenis prekursor. Komposisi $\mathrm{Cu}$ dalam katalis divariaskani dari 0,2\% hingga 5\%. Fotokatalis tersebut kemudian dikarakterisasi DRS (Diffuse Reflectance Spectroscopy) dan XRD (X-Ray Diffraction). Aktivitas fotokatalis diuji dengan menggunakan sistem reaktor slurry yang bekerja secara batch dan dilengkapi dengan 6 lampu UV black light selama 5 jam, kemudian hasilnya dianalisis dengan UV-VIS Spectrophotometer. Hasil karakterisasi DRS menunjukan bahwa penambahan CuO dari 1\% hingga $5 \%$ ke dalam $\mathrm{TiO}_{2}$ dapat meningkatkan pita absorbansi katalis dari 398 hingga $413 \mathrm{~nm}$ dan menurunkan band gap dari 3,2 hingga 2,58 eV. Hasil karakterisasi XRD menunjukan adanya struktur kristal anatase dan rutil dalam katalis $\mathrm{TiO}_{2}$ dan $\mathrm{CuO} / \mathrm{TiO} \mathrm{O}_{2}$, sementara struktur kristal CuO muncul pada katalis $\mathrm{CuO} / \mathrm{TiO}_{2}$ yang dipreparasi dengan prekursor Cu-Asetat dan Cu-Nitrat. Fotokatalis 0,2\% $\mathrm{CuO} / \mathrm{TiO}_{2}$ dari prekursor Cu-Asetat memiliki aktivitas optimal yang mereduksi $\mathrm{Cr}(\mathrm{VI})$ 99,67\% dan mendegradasi fenol 97,16\%. Sementara jika kedua limbah tersebut diolah secara simultan, katalis $\mathrm{TiO}_{2}$ Degussa P25 memiliki aktivitas yang paling tinggi dengan meningkatkan konversi reduksi Cr(VI) menjadi 100\% dan menurunkan konversi degradasi fenol menjadi 93,81\% dengan waktu reaksi 5 jam.
\end{abstract}

Kata kunci: $\mathrm{CuO} / \mathrm{TiO}_{2}$; fotokatalis; degradasi fenol; reduksi $\mathrm{Cr}(\mathrm{VI})$

\section{Pendahuluan}

Pesatnya perkembangan aktivitas perindustrian akhir-akhir ini telah menyebabkan permasalahan lingkungan, akibat bertambahnya limbah berbahaya yang dihasilkan industri tersebut. Beberapa limbah berbahaya yang menjadi perhatian masyarakat sekarang ini diantaranya adalah limbah $\mathrm{Cr}(\mathrm{VI})$ dan fenol.

Baik Cr(VI) maupun fenol bersifat racun terhadap semua organisme dan menyebabkan iritasi serta korosi pada kulit manusia. Mengingat bahaya yang ditimbulkannya, maka perlu dilakukan penanganan khusus terhadap limbah $\mathrm{Cr}(\mathrm{VI})$ dan fenol tersebut. Teknologi konvensional telah banyak dilakukan untuk mengolah limbah $\mathrm{Cr}(\mathrm{VI})$ dan fenol, tetapi metode tersebut masih memiliki beberapa kelemahan, diantaranya efisiensi pengolahan limbah yang rendah, pemakaian energi dan bahan kimia yang cukup tinggi, serta proses pengolahan limbah yang dilakukan tersebut ternyata masih menghasilkan residu berbahaya (Khalil dkk., 1998; Dingwangchen dkk., 1999; Ku dkk., 2001).

Teknologi fotokatalisis yang sekarang ini banyak dikembangkan ternyata juga baik untuk mereduksi Cr(VI) dan fenol. Bahkan, dinilai lebih ekonomis dalam pemakaian energi. Selain itu, teknologi fotokatalis juga dapat menekan pemakaian bahan kimia. Dengan demikian, fotokatalisis merupakan salah satu alternatif metode yang lebih ekonomis.

Katalis semikonduktor yang sampai saat ini terbukti memiliki aktivitas tinggi dalam reduksi limbah $\mathrm{Cr}(\mathrm{VI})$ dan fenol adalah $\mathrm{TiO}_{2}$. Begitu banyak cara telah dilakukan untuk meningkatkan aktivitas katalis $\mathrm{TiO}_{2}$ tersebut, salah satunya dengan penambahan dopan logam, seperti logam Pt. Logam lainnya yang dapat ditambahkan sebagai dopan adalah logam $\mathrm{Cu}$ dalam bentuk oksidanya, yaitu $\mathrm{CuO}$, yang telah terbukti lebih aktif dari titania untuk mereduksi $\mathrm{CO}_{2}$ menjadi metanol (Slamet dkk, 2005).

Bokhimi dkk (1999) mengatakan bahwa penggunaan prekursor $\mathrm{CuO}$ yang berbeda memiliki pengaruh signifikan terhadap karakteristik dan aktivitas dari katalis semikonduktor $\mathrm{TiO}_{2}$.

Penggunaan katalis $\mathrm{TiO}_{2}$ dengan penambahan dopan $\mathrm{CuO}$ untuk reduksi limbah $\mathrm{Cr}(\mathrm{VI})$ dan fenol belum banyak diteliti. Oleh karena itu, pada penelitian ini akan dijelaskan mengenai pengolahan limbah $\mathrm{Cr}(\mathrm{VI})$ dan fenol pada sistem terpisah dan simultan secara fotokatalisis dengan katalis $\mathrm{TiO}_{2}$ dan $\mathrm{CuO} / \mathrm{TiO}_{2}$ yang dibagi dalam tiga tahap, yaitu preparasi, karakterisasi (DRS dan XRD) dan uji aktivitas dari katalis $\mathrm{CuO} / \mathrm{TiO}_{2}$.

\footnotetext{
$\left.{ }^{*}\right)$ Departemen Teknik Kimia, Fakultas Teknik, Universitas Indonesia

Kampus Baru UI Depok 16424, Telp. (021) 7863576. E-mail: slamet@che.ui.edu
} 


\section{Metode Penelitian}

Preparasi katalis $\mathrm{CuO} / \mathrm{TiO}_{2}$

Preparasi katalis $\mathrm{CuO} / \mathrm{TiO}_{2}$ dilakukan dengan metode impregnasi termodifikasi menggunakan $\mathrm{Cu}\left(\mathrm{NO}_{3}\right)_{2} \cdot 3 \mathrm{H}_{2} \mathrm{O}$ (Merck 99,5\%), $\left(\mathrm{CH}_{3} \mathrm{COO}\right)_{2} \mathrm{Cu} . \mathrm{H}_{2} \mathrm{O}$ (Merck 99\%), $\mathrm{CuSO}_{4}$ (Merck 99\%) dan $\mathrm{CuCl}_{2} \cdot 2 \mathrm{H}_{2} \mathrm{O}$ (Merck 99\%) sebagai prekursor penghasil dopan $\mathrm{CuO}$. Bahan awal $\mathrm{TiO}_{2}$ digunakan $\mathrm{TiO}_{2}$ komersial Degussa P25. Komposisi $\mathrm{Cu}$ divariasikan dari 0,2-5\% berat.

$\mathrm{TiO}_{2}$ dan bahan prekursor $\mathrm{CuO}$ dengan perbandingan berat tertentu, dimasukkan ke dalam 50 $\mathrm{mL}$ air demin (air bebas mineral), diaduk hingga membentuk larutan suspensi dan dilanjutkan dengan ultrasonifikasi selama 1 jam. Larutan suspensi dipanaskan di atas hot plate-stirrer, yang dilengkapi dengan magnetic stirrer, pada suhu $90^{\circ} \mathrm{C}$ selama \pm 3 jam. Selanjutnya, dilakukan pengeringan dalam vacuum furnace pada suhu $150^{\circ} \mathrm{C}$ selama 2 jam. Kemudian dipindahkan ke dalam atmospheric furnace dan dikalsinasi pada suhu $500^{\circ} \mathrm{C}$ selama 0,5 jam dengan laju kenaikan suhu sebesar $5^{\circ} \mathrm{C} /$ menit.

\section{Karakterisasi katalis $\mathrm{CuO} / \mathrm{TiO}_{2}$}

Karakterisasi DRS menggunakan Spectrophotometer tipe CARY 2415 UV/Vis NIR yang dilengkapi dengan sphere terintegrasi untuk merekam diffuse reflectance spectra (DRS) dan data absorbansi sampel yang diamati. Spektrum reflektan dianalisis pada kondisi ambient pada panjang gelombang 340-700 nm.

Karakterisasi XRD bertujuan untuk mengidentifikasi struktur kristal dari katalis $\mathrm{CuO} / \mathrm{TiO}_{2}$ dengan kandungan $\mathrm{Cu}$ 5\% dari empat prekursor yang berbeda, menggunakan XRD tipe PHILIPS PW 1710 dengan tabung anode $\mathrm{Cu}(\lambda=0,154184 \mathrm{~nm})$. Ukuran kristal sampel juga diperoleh dari setengah lebar puncak maksimum dari XRD dengan persamaan Scherrer.

Tabung XRD dijalankan pada tegangan $40 \mathrm{kV}$ dan arus sebesar $30 \mathrm{~mA}$, step size diatur sebesar $0,01^{\circ}$ dan time per step diatur pada 1,0 sekon, $2 \theta=20-60^{\circ}$. Puncak sampel hasil karakterisasi XRD dibandingkan dengan puncak standar yang diperoleh dari piranti lunak PCPDFWIN versi 2.01. Hasil karakterisasi pola difraksi sinar-X untuk setiap sampel di-fitting terlebih dahulu dengan menggunakan piranti lunak PC APD versi 3.5B.

\section{Reaksi fotokatalisis}

Reaksi fotokatalisis dilakukan dalam reaktor fotokatalisis jenis slurry yang bekerja secara batch. Reaktor terdiri dari tabung pyrex dengan tinggi $5 \mathrm{~cm}$, diameter $14 \mathrm{~cm}$, bagian atasnya terbuka dan berjarak 8 cm dari lampu UV sebanyak 6 buah merek TOKI Japan @ 10 watt, dengan intensitas $2450 \mu \mathrm{W} / \mathrm{m}^{2}$.

Tiga ratus $\mathrm{mL}$ limbah dibuat dengan konsentrasi awal $40 \mathrm{ppm}$ dan kondisi $\mathrm{pH}$ optimal diatur untuk masing-masing limbah. Spesifikasi $\mathrm{pH}$ dari jenis limbah yang dibuat dapat dilihat pada Tabel 1.

Tabel 1. Spesifikasi jenis dan kondisi pH limbah

\begin{tabular}{lc}
\hline \multicolumn{1}{c}{ Jenis Limbah } & pH \\
\hline Limbah Cr(VI), 40 ppm & 2 \\
Limbah Fenol, 40 ppm & 7 \\
Limbah Cr(VI) + Fenol, 40 ppm & 2 \\
\hline
\end{tabular}

Fotokatalis dengan berat tertentu dilarutkan ke dalam $100 \mathrm{~mL}$ limbah yang kemudian diultrasonik selama 45 menit. Sisa larutan limbah dimasukan ke dalam reaktor terlebih dahulu. Lampu reaktor, pengontrol pengaduk dan kipas dinyalakan sampai kondisi temperatur reaktor konstant ( \pm 1 jam). Hal ini dilakukan untuk analisis blank test, guna meyakinkan bahwa produk yang dihasilkan berasal dari proses fotokatalisis. Kemudian, katalis yang sudah diultrasonik dimasukkan ke dalam larutan limbah sehingga volume total menjadi $300 \mathrm{~mL}$.

Reaktor dioperasikan selama 5 jam dan sampel diambil setiap jam. Sampel kemudian disentrifuge selama 1 jam dan dianalisis dengan UV-VIS Spectrophotometer buatan Labomed.Inc tipe Spectro UV-VIS RS. Kondisi operasi panjang gelombang untuk analisis Cr(VI) $398 \mathrm{~nm}$ dan fenol $500 \mathrm{~nm}$.

\section{Hasil dan Pembahasan}

\section{Karakterisasi katalis $\mathrm{CuO} / \mathrm{TiO}_{2}$}

Spektra DRS dari katalis yang dipreparasi berdasarkan variasi komposisi $\mathrm{Cu}$ pada bahan prekursor yang berbeda-beda dapat dilihat pada Gambar 1.

Dari hasil spektra DRS terlihat bahwa peningkatan komposisi $\mathrm{Cu} 1-5 \%$ pada katalis $\mathrm{CuO} / \mathrm{TiO}_{2}$, yang dipreparasi dari prekursor $\mathrm{Cu}-$ Nitrat dan $\mathrm{Cu}$-Asetat, menyebabkan peningkatan absorbansi katalis $\mathrm{CuO} / \mathrm{TiO}_{2}$, sementara katalis yang dipreparasi dari prekursor Cu-Klorida dan Cu-Sulfat, peningkatan yang terjadi tidak signifikan. Dari pola pergeseran spektra absorbansi dapat dilihat bahwa peningkatan kandungan $\mathrm{Cu}$ 1-5\% menyebabkan pergeseran pita absorbansi ke arah pita cahaya sinar tampak, sehingga katalis memiliki kemampuan lebih untuk menyerap cahaya pada panjang gelombang yang lebih tinggi.

Melalui karakterisasi DRS juga dapat diperoleh nilai band gap katalis. Pada Tabel 2 terlihat bahwa penambahan $\mathrm{Cu} 1-5 \%$ pada katalis $\mathrm{CuO} / \mathrm{TiO}_{2}$, yang dipreparasi dari prekursor $\mathrm{Cu}-\mathrm{Asetat}, \mathrm{Cu}-\mathrm{Nitrat}, \mathrm{Cu}-$ Klorida, dan Cu-Sulfat, meningkatkan pita absorbansi katalis berturut-turut 398-442 nm, 398-482 nm, 398$430 \mathrm{~nm}, 398-413 \mathrm{~nm}$ dan menurunkan nilai band gap katalis 3,2-2,81 eV, 3,2-2,58 eV, 3,2-2,89 eV dan 3,2$3,01 \mathrm{eV}$. Hal ini sesuai dengan penelitian yang dilakukan oleh Chiang dkk (2002), bahwa peningkatan kandungan $\mathrm{Cu}$ meningkatkan absorbansi katalis dari $395 \mathrm{~nm}$ menjadi 405-450 nm. 

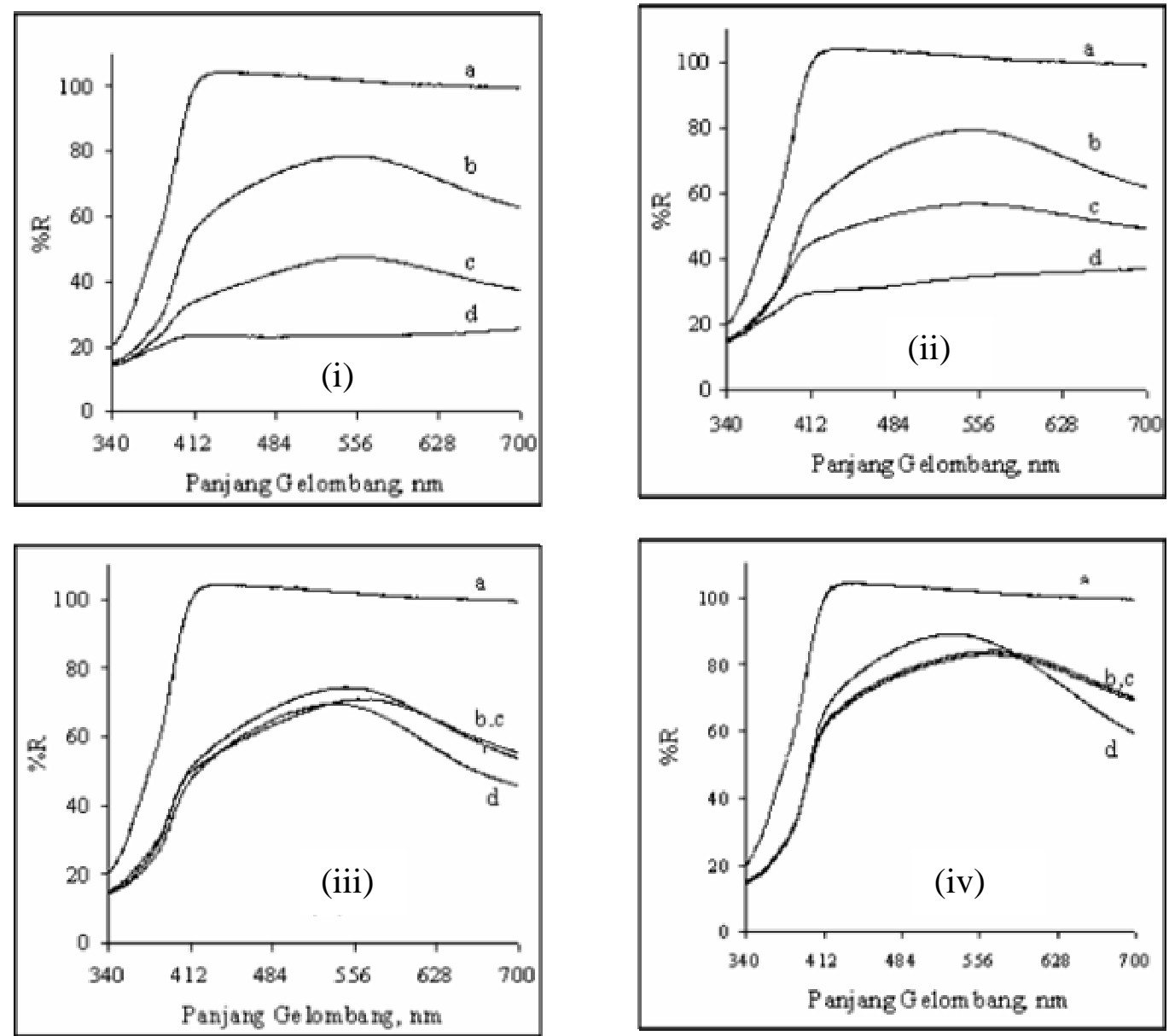

Gambar 1. Spektra DRS dari $\mathrm{TiO}_{2}$ dan $\mathrm{CuO} / \mathrm{TiO}_{2}$ pada precursor: (i) Cu-Nitrat; (ii) Cu-Asetat; (iii) Cu-Klorida;

(iv) Cu-Sulfat. Keterangan kurva: a. $\mathrm{TiO}_{2}$; b. $1 \% \mathrm{CuO} / \mathrm{TiO}_{2}$; c. $3 \% \mathrm{CuO} / \mathrm{TiO}_{2}$; d. $5 \% \mathrm{CuO} / \mathrm{TiO}_{2}$

Tabel 2. Energi band gap katalis untuk berbagai kandungan $\mathrm{Cu}$

\begin{tabular}{lcc}
\hline \multicolumn{1}{c}{ Sampel } & Panjang Gelombang (nm) & Band gap (eV) \\
\hline Degussa P25 & 398 & 3,20 \\
1 \% CuO/P25 ( Cu-Nitrat ) & 418 & 2,97 \\
3 \% CuO/P25 ( Cu-Nitrat ) & 439 & 2,83 \\
$5 \% \mathrm{CuO} / \mathrm{P} 25$ ( Cu-Nitrat ) & 482 & 2,58 \\
1 \% CuO/P25 ( Cu-Sulfat ) & 407 & 3,05 \\
3 \% CuO/P25 ( Cu-Sulfat ) & 412 & 3,01 \\
$5 \% \mathrm{CuO} / \mathrm{P} 25$ ( Cu-Sulfat ) & 413 & 3.01 \\
1 \% CuO/P25 ( Cu-Asetat ) & 418 & 2,97 \\
3 \% CuO/P25 ( Cu-Asetat ) & 427 & 2,91 \\
5 \% CuO/P25 ( Cu-Asetat ) & 442 & 2,81 \\
1 \% CuO/P25 ( Cu-Klorida ) & 418 & 2,97 \\
3 \% CuO/P25 ( Cu-Klorida ) & 420 & 2,96 \\
5 \% CuO/P25 ( Cu-Klorida ) & 430 & 2,89
\end{tabular}

Pola difraksi XRD dari katalis $\mathrm{CuO} / \mathrm{TiO}_{2}$ dengan kandunagan $\mathrm{Cu}$ 5\% untuk prekursor berbeda dapat dilihat pada Gambar 2. Pada gambar terlihat bahwa struktur kristal anatase muncul pada $2 \theta=25,34^{\circ}$ dan rutil pada $2 \theta=27,42^{\circ}$. Sementara struktur kristal $\mathrm{CuO}\left(2 \theta=35,6^{\circ}\right)$ hanya muncul pada katalis $\mathrm{CuO} / \mathrm{TiO}_{2}$ yang dipreparasi dari prekursor $\mathrm{Cu}-$ Asetat dan $\mathrm{Cu}-$ Nitrat. Dari Tabel 3 dapat disimpulkan bahwa variasi prekursor tidak memiliki pengaruh yang signifikan terhadap perubahan ukuran kristal anatase (18-21 nm) dan rutil (23-32 nm). Sementara untuk ukuran kristal $\mathrm{CuO}$, pada katalis $\mathrm{CuO} / \mathrm{TiO}_{2}$, yang dipreparasi dari prekursor $\mathrm{Cu}$-Asetat memiliki ukuran kristal lebih 
kecil dibandingkan dengan katalis $\mathrm{CuO} / \mathrm{TiO}_{2}$ yang dipreparasi dari prekursor Cu-Nitrat. Pada Tabel 3 terlihat bahwa modifikasi katalis $\mathrm{TiO}_{2}$ dengan dopan $\mathrm{CuO}$ pada katalis $5 \% \quad \mathrm{CuO} / \mathrm{TiO}_{2}$ menurunkan komposisi kristal anatase. Hal ini disebabkan karena pada preparasi katalis $\mathrm{CuO} / \mathrm{TiO}_{2}$ terdapat proses kalsinasi yang merubah fasa anatase menjadi fasa rutil, sementara untuk $\mathrm{TiO}_{2}$ tidak.

Tidak signifikannya pengaruh penambahan $\mathrm{Cu}$ terhadap peningkatan pita absorbansi katalis dan penurunan nilai band gap katalis, serta tidak munculnya struktur kristal $\mathrm{CuO}$ pada katalis $\mathrm{CuO} / \mathrm{TiO}_{2}$ yang dipreparasi dari prekursor Cu-Klorida dan Cu-Sulfat, disebabkan karena belum terbentuknya kristal $\mathrm{CuO}$ pada katalis $\mathrm{CuO} / \mathrm{TiO}_{2}$ yang dipreparasi dari prekursor $\mathrm{Cu}-\mathrm{Kl}$ lorida dan $\mathrm{Cu}-\mathrm{Sulfat}$ pada temperatur kalsinasi $500^{\circ} \mathrm{C}$. Jika dilihat dari rumus molekul yang dimiliki oleh masing-masing prekursor yang digunakan, untuk Cu-Asetat, Cu-Nitrat dan Cu-Sulfat, ketiganya memiliki gugus oksigen, sementara untuk Cu-Klorida tidak ada. Hal tersebut membuktikan bahwa ketiga prekursor memiliki kesempatan lebih besar untuk terdekomposisi menjadi kristal CuO.

Dalam Encyclopedia of Chemistry tertulis bahwa $\mathrm{CuO}$ bisa dibentuk dari $\mathrm{CuSO}_{4}$ melalui proses dekomposisi termal pada temperatur $600-700^{\circ} \mathrm{C}$ dan $\mathrm{CuO}$ juga bisa dibentuk dari $\mathrm{Cu}(\mathrm{SO})_{4} \cdot 5 \mathrm{H}_{2} \mathrm{O}$ dengan proses reaksi sebagai berikut:

$$
\begin{aligned}
& 88^{\circ} \mathrm{C} \quad 114^{\circ} \mathrm{C} \\
& \mathrm{Cu}(\mathrm{SO})_{4} \cdot 5 \mathrm{H}_{2} \mathrm{O} \rightarrow \mathrm{CuSO}_{4} \cdot 3 \mathrm{H}_{2} \mathrm{O} \rightarrow \mathrm{CuSO}_{4} \cdot \mathrm{H}_{2} \mathrm{O} \\
& 245^{\circ} \mathrm{C} \quad 340^{\circ} \mathrm{C} \quad 600^{\circ} \mathrm{C} \\
& \rightarrow \quad 3 \mathrm{Cu}(\mathrm{OH})_{2} \cdot \mathrm{CuSO}_{4} \rightarrow \mathrm{CuSO}_{4} \rightarrow \mathrm{CuO}
\end{aligned}
$$

Dari Tabel 2 terlihat bahwa nilai band gap untuk katalis yang dipreparasi dengan prekursor $\mathrm{Cu}$ Sulfat masih tinggi karena kondisi temperatur kalsinasi yang digunakan masih belum optimum, sehingga disinyalir masih adanya garam sulfat dalam katalis CuO. Maka untuk menurunkan nilai band gap, temperatur kalsinasinya perlu ditingkatkan. Begitu pula dengan katalis $\mathrm{CuO} / \mathrm{TiO}_{2}$ yang dipreparasi dari prekursor Cu-Klorida.

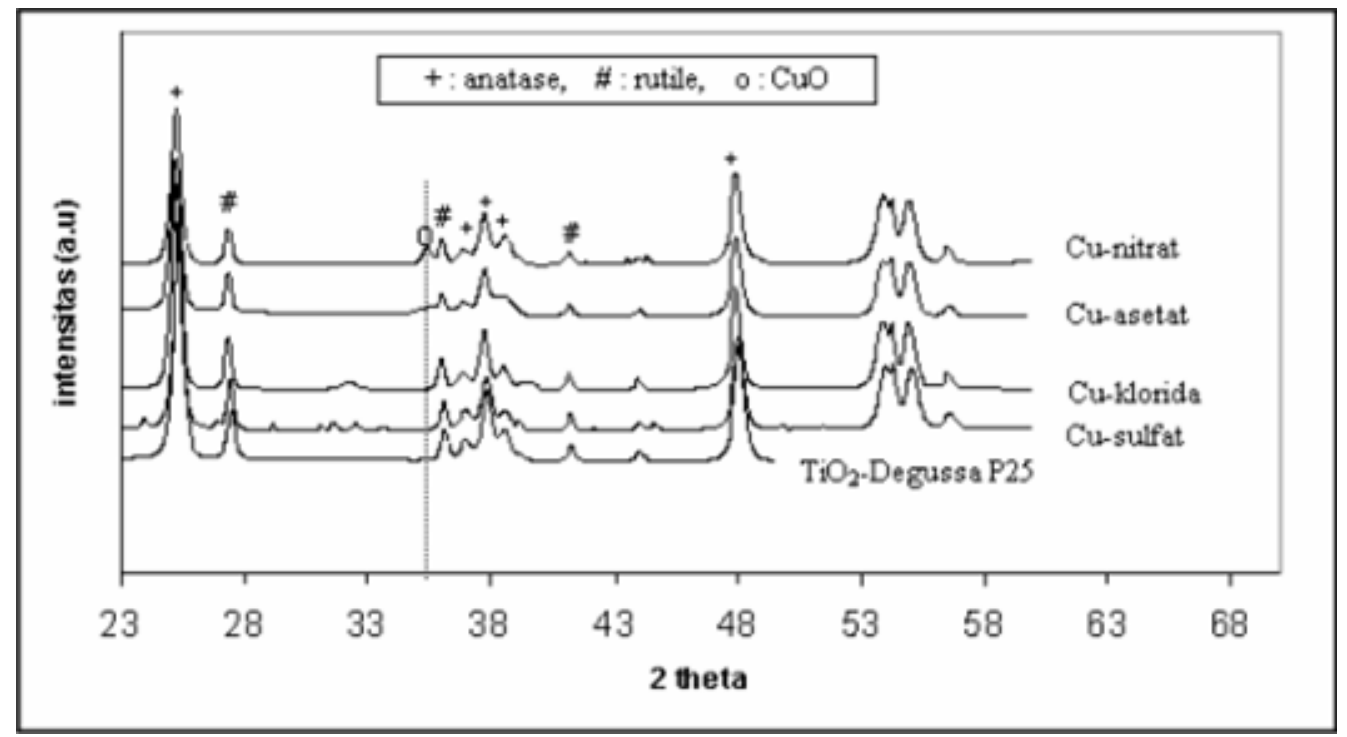

Gambar 2. Pola difraksi XRD katalis $\mathrm{TiO}_{2}$ Degussa $\mathrm{P} 25$ dan $\mathrm{CuO} / \mathrm{TiO}_{2}$ dengan variasi prekursor

Tabel 3. Hasil Karakterisasi XRD pada katalis $\mathrm{TiO}_{2}$ Degussa P25 dan $\mathrm{CuO} / \mathrm{TiO}_{2}$

\begin{tabular}{lccccc}
\hline \multirow{2}{*}{ Sampel } & \multicolumn{2}{c}{ Ukuran Kristal (nm) } & \multicolumn{2}{c}{ Komposisi TiO } \\
\cline { 2 - 6 } & Anatase & Rutil & CuO & Anatase & Rutil \\
\hline $\mathrm{TiO}_{2}$ Degussa P25 & 20 & 23 & 0 & 79.23 & 20.77 \\
$5 \% \mathrm{CuO} / \mathrm{TiO}_{2}$ (Cu-Nitrat) & 19 & 23 & 18 & 74.88 & 25.12 \\
$5 \% \mathrm{CuO} / \mathrm{TiO}_{2}$ (Cu-Asetat) & 18 & 26 & 10 & 70.75 & 29.25 \\
$5 \% \mathrm{CuO} / \mathrm{TiO}_{2}$ (Cu-Klorida) & 21 & 32 & 0 & 73.61 & 26.39 \\
$5 \% \mathrm{CuO} / \mathrm{TiO}_{2}$ (Cu-Sulfat) & 20 & 30 & 0 & 73.11 & 26.89 \\
\hline
\end{tabular}


Bokhimi dkk (1999) juga menemukan hal yang sama. Melalui penelitian yang dilakukannya, hasil karakterisasi XRD menunjukkan bahwa katalis $\mathrm{CuO} / \mathrm{TiO}_{2}$ yang dipreparasi dengan prekursor $\mathrm{Cu}-$ Klorida dan $\mathrm{Cu}-S u l f a t$, puncak $\mathrm{CuO}$ tidak muncul apabila dikalsinasi pada temperatur $400^{\circ} \mathrm{C}$, tetapi baru muncul apabila proses kalsinasi dilakukan pada temperatur $800^{\circ} \mathrm{C}$ (Bokhimi dkk, 1999).

\section{Reaksi fotokatalisis}

Reaksi fotokatalisis dilakukan pada proses pengolahan limbah $\mathrm{Cr}(\mathrm{VI})$ dan fenol. Kondisi operasi proses reaksi yang diatur untuk mendapatkan hasil optimal diantaranya adalah konsentrasi awal limbah dan $\mathrm{pH}$ larutan. Konsentrasi awal limbah yang akan diolah sebesar $40 \mathrm{mg} / \mathrm{L}$. Hal ini berdasarkan atas penelitian terdahulu yang mendapatkan hasil bahwa konsentrasi awal limbah yang optimum sebesar 40 mg/L (Syakur, 2002).

Pada Limbah Cr(VI), larutan diatur pada kondisi $\mathrm{pH}=2$. Pada penelitian yang dilakukan oleh $\mathrm{Ku}$ dkk (2001) diperoleh $\mathrm{pH}=2$ merupakan kondisi yang optimal (Ku dkk, 2001). Sementara untuk larutan fenol dilakukan pada kondisi netral $(\mathrm{pH}=7)$. Pada pengolahan limbah secara simultan kondisi larutan diatur pada $\mathrm{pH}=2$. Dalam paper ini tidak dibahas aspek mekanisme dan kinetika reaksinya.

\section{Pengaruh waktu reaksi}

Pada Gambar 3 terlihat bahwa peningkatan waktu reaksi menyebabkan bertambahnya jumlah $\mathrm{Cr}(\mathrm{VI})$ yang tereduksi. Akan tetapi, ketika waktu reaksi lebih dari lima jam terlihat bahwa jumlah Cr(VI) yang tereduksi tidak mengalami peningkatan lagi (konstan). Hal tersebut menunjukkan bahwa waktu reaksi lima jam merupakan waktu yang optimal untuk proses reduksi. Penambahan waktu proses reduksi tidak berpengaruh signifikan terhadap pengurangan konsentrasi $\mathrm{Cr}(\mathrm{VI})$.

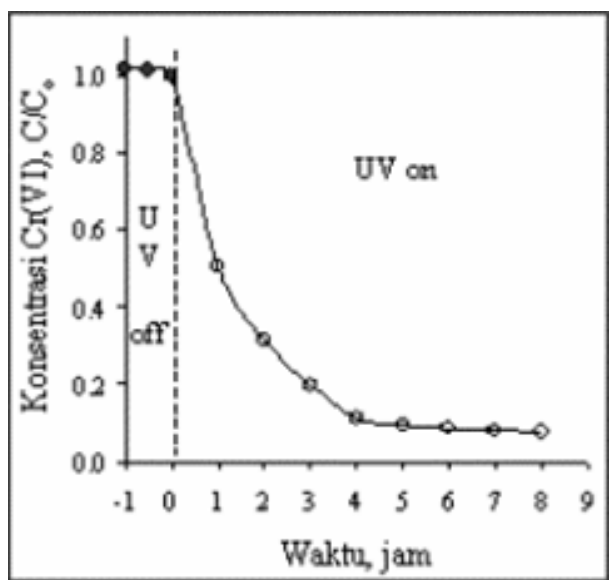

Gambar 3. Pengaruh waktu reaksi pada reduksi Cr(VI) dengan $\mathrm{TiO}_{2} / \mathrm{P} 253 \mathrm{~g} / \mathrm{L}$ pada $\mathrm{pH}=2$ dan $\mathrm{C}_{0}=40 \mathrm{ppm}$.

\section{Pengaruh konsistensi katalis terhadap reduksi limbah Cr(VI)}

Dalam penelitian ini dilakukan reaksi fotoreduksi $\mathrm{Cr}(\mathrm{VI})$ dengan variasi konsistensi katalis sebesar 0,$5 ; 1 ; 1,5 ; 2 ; 3$ dan 7 g/L. Data aktivitas katalis untuk reduksi $\mathrm{Cr}(\mathrm{VI})$ dengan variasi konsistensi katalis dapat dilihat pada Gambar 4.

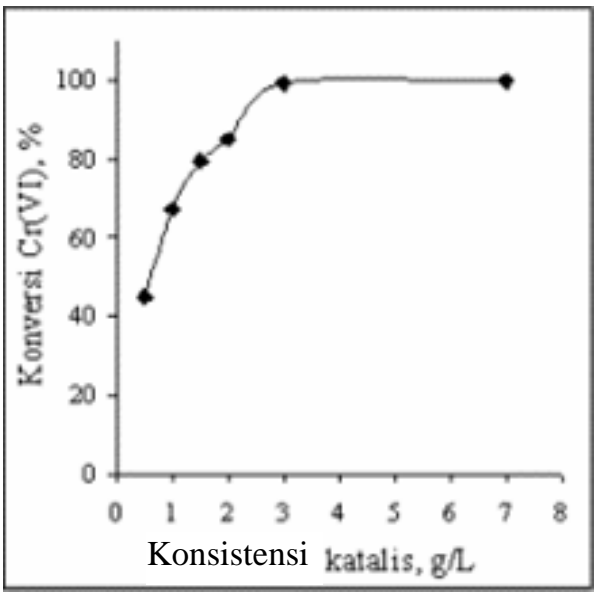

Gambar 4. Pengaruh konsistensi katalis terhadap reduksi $\mathrm{Cr}(\mathrm{VI})\left(\mathrm{pH}=2, \mathrm{t}=5\right.$ jam dan $\left.\mathrm{C}_{0}=40 \mathrm{ppm}\right)$.

Pada Gambar 4 terlihat bahwa peningkatan konsistensi $\mathrm{TiO}_{2}$ menyebabkan peningkatan fotoreduksi dari $\mathrm{Cr}(\mathrm{VI})$. Akan tetapi, kenaikan konsistensi katalis memiliki batas optimal, dimana peningkatan persen konversi yang diperoleh tidak terlalu signifikan diantara penggunaan katalis $\mathrm{TiO}_{2} 3 \mathrm{~g} / \mathrm{L}$ dengan $7 \mathrm{~g} / \mathrm{L}$. Hal tersebut menandakan bahwa nilai optimal telah dicapai dan apabila konsistensi $\mathrm{TiO}_{2}$ terus ditambahkan akan menurunkan laju fotoreduksi $\mathrm{Cr}(\mathrm{VI})$, karena banyaknya partikel $\mathrm{TiO}_{2}$ yang berada dalam larutan menghalangi penetrasi sinar UV ke dalam katalis $\mathrm{TiO}_{2}$ yang berada di bagian dalam. Sebaliknya, jika konsistensi katalis yang digunakan lebih sedikit dari nilai optimal, akan mengurangi luas permukaan katalis yang digunakan untuk fotoreduksi sehingga laju reduksi akan turun. Penggunaan katalis sebanyak $3 \mathrm{~g} / \mathrm{L}$ akan dipakai terus untuk uji aktivitas katalis pada penelitian ini.

\section{Pengaruh prekursor terhadap pengolahan limbah}

Prekursor sebagai bahan awal pembuat dopan ternyata juga memiliki pengaruh terhadap aktivitas katalis $\mathrm{CuO} / \mathrm{TiO}_{2}$. Berdasarkan pernyataan tersebut, dalam penelitian ini dilakukan uji aktivitas terhadap katalis $\mathrm{CuO} / \mathrm{TiO}_{2}$ untuk jenis prekursor $\mathrm{Cu}-N i t r a t, \mathrm{Cu}-$ Asetat, Cu-Klorida dan Cu-Sulfat pada dua jenis limbah yang berbeda. Pada Gambar 5 bisa dilihat kurva hasil uji aktivitas katalis $\mathrm{CuO} / \mathrm{TiO}_{2}$ dengan jenis prekursor yang berbeda untuk pengolahan dua jenis limbah. 


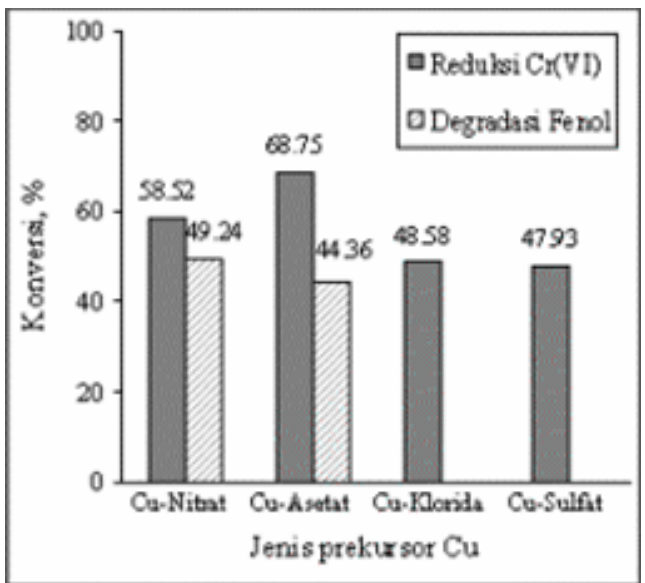

Gambar 5. Pengaruh prekursor Cu dalam 1\% $\mathrm{CuO} / \mathrm{TiO}_{2}$ terhadap reduksi $\mathrm{Cr}(\mathrm{VI})$ dan degradasi fenol pada sistem terpisah ( $\mathrm{t}=5 \mathrm{jam}, \mathrm{pH}=2$ untuk reduksi $\mathrm{Cr}(\mathrm{VI})$ dan $\mathrm{pH}=7$ untuk degradasi fenol,

$$
\left.\mathrm{C}_{0}=40 \mathrm{ppm}\right)
$$

Pada Gambar 5 terlihat bahwa katalis $\mathrm{CuO} / \mathrm{TiO}_{2}$ yang dipreparasi dari prekursor $\mathrm{Cu}$-Asetat dan Cu-Nitrat memiliki aktivitas lebih tinggi dibandingkan katalis $\mathrm{CuO} / \mathrm{TiO}_{2}$ yang dipreparasi dari prekursor $\mathrm{Cu}-\mathrm{Kl}$ lorida dan $\mathrm{Cu}$-Sulfat. Hal ini sesuai dengan data karakterisasi XRD yang menyatakan bahwa pada katalis yang berasal dari prekursor $\mathrm{Cu}-$ Asetat dan Cu-Nitrat telah terbentuk kristal $\mathrm{CuO}$, sementara untuk $\mathrm{Cu}-\mathrm{Kl}$ lorida dan $\mathrm{Cu}-\mathrm{Sulfat}$ tidak.

Apabila dibandingkan antara Cu-Asetat dengan $\mathrm{Cu}-\mathrm{Nitrat}$, katalis yang dipreparasi dari prekursor $\mathrm{Cu}-$ Asetat memiliki aktivitas lebih tinggi dibandingkan dengan Cu-Nitrat. Hal ini disebabkan karena pada katalis yang dipreparasi dengan prekursor $\mathrm{Cu}$-Asetat memiliki ukuran kristal CuO lebih kecil dibandingkan ukuran kristal $\mathrm{CuO}$ yang dipreparasi dengan prekursor $\mathrm{Cu}-\mathrm{Nitrat}$, sehingga luas permukaannya lebih besar dan permukaan $\mathrm{TiO}_{2}$ yang tertutupi tidak banyak.

Apabila dikaitkan dengan nilai band gap dari data karakterisasi DRS, katalis $1 \% \mathrm{CuO} / \mathrm{TiO}_{2}$ yang dipreparasi dari prekusor $\mathrm{Cu}-\mathrm{Nitrat}$ dan $\mathrm{Cu}$-Asetat memiliki nilai band gap yang sama. Hal itu menunjukan bahwa berdasarkan nilai band gap, seharusnya kedua katalis tersebut memiliki aktivitas katalis yang sama. Akan tetapi pada Gambar 5 menunjukan hasil yang bertentangan. Sehingga dapat disimpulkan ukuran kristal $\mathrm{CuO}$ merupakan faktor yang lebih dominan dibandingkan nilai band gap dalam mempengaruhi aktivitas katalis. Fenomena yang sama juga terjadi pada pengolahan limbah secara simultan antara limbah $\mathrm{Cr}(\mathrm{VI})$ dengan fenol, seperti terlihat pada Gambar 6.

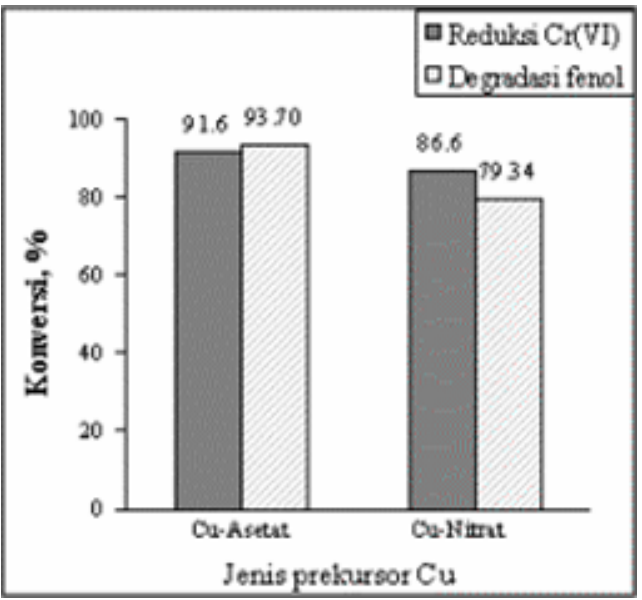

Gambar 6. Pengaruh prekursor Cu dalam 1\% $\mathrm{CuO} / \mathrm{TiO}_{2}$ terhadap reduksi $\mathrm{Cr}(\mathrm{VI})$ dan degradasi fenol pada sistem simultan $(\mathrm{t}=5 \mathrm{jam}, \mathrm{pH}=2$ untuk reduksi $\mathrm{Cr}(\mathrm{VI})$ dan $\mathrm{pH}=7$ untuk degradasi fenol,

$$
\left.\mathrm{C}_{0}=40 \mathrm{ppm}\right)
$$

\section{Pengaruh komposisi $\mathrm{Cu}$}

Selain jenis prekursor, yang berpengaruh terhadap aktivitas katalis $\mathrm{CuO} / \mathrm{TiO}_{2}$ adalah komposisi $\mathrm{Cu}$ yang ditambahkan pada katalis tersebut. $\mathrm{Cu}$-Asetat sebagai prekursor yang optimal untuk mengolah limbah $\mathrm{Cr}(\mathrm{VI})$ dan fenol, baik secara terpisah dan simultan, selanjutnya diuji dengan variasi komposisi Cu. Hasil pengujian dapat dilihat pada Gambar 7.

Dari Gambar 7 dapat dilihat bahwa katalis $\mathrm{CuO} / \mathrm{TiO}_{2}$ dengan komposisi $\mathrm{Cu} \quad 0,2 \%$ memiliki aktivitas optimal dibandingkan katalis lainnya. Semakin meningkat komposisi $\mathrm{Cu}$ pada katalis $\mathrm{CuO} / \mathrm{TiO}_{2}$ menyebabkan aktivitasnya semakin menurun. Hal ini disebabkan karena pada katalis $\mathrm{CuO} / \mathrm{TiO}_{2}$ dengan $\mathrm{Cu}$ di atas $0,2 \%$, permukaan aktif dari $\mathrm{TiO}_{2}$ tertutupi oleh kristal $\mathrm{CuO}$ sehingga menurunkan aktivitas katalis. Dengan demikian, penambahan dopan $\mathrm{CuO}$ yang semula dapat mencegah terjadinya rekombinasi elektron-hole tidak berperan secara optimal, melainkan $\mathrm{CuO}$ berfungsi sebagai penghalang terjadinya reaksi reduksi $\mathrm{Cr}(\mathrm{VI})$ maupun degradasi fenol. Sebaliknya untuk komposisi $\mathrm{Cu} 0,2 \%$, kristal $\mathrm{CuO}$ berfungsi sebagai dopan sehingga dapat berperan sebagai penangkap elektron yang mencegah terjadinya rekombinasi elektron-hole sehingga meningkatkan aktivitas katalis.

Hal tersebut memberikan hasil yang bertentangan terhadap hasil karakterisasi DRS. Berdasarkan karakterisasi DRS, peningkatan jumlah $\mathrm{Cu}$ dapat meningkatkan aktivitas katalis karena energi band gap yang dibutuhkan untuk mengeksitasi elektron dari pita valensi ke pita konduksi semakin kecil. Maka dapat disimpulkan bahwa band gap bukan merupakan faktor dominan yang mempengaruhi aktivitas dari katalis. 

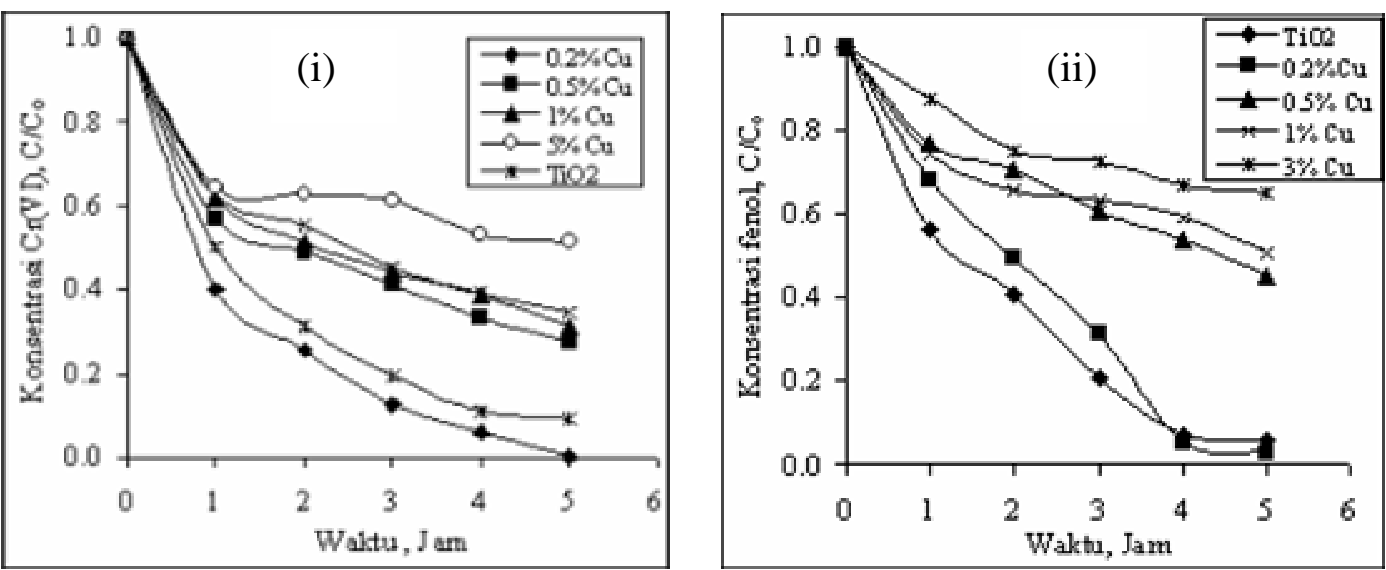

Gambar 7. Pengaruh komposisi Cu pada katalis $\mathrm{CuO} / \mathrm{TiO}_{2}$ yang dipreparasi dari prekursor $\mathrm{Cu}-$ Asetat terhadap: (i) reduksi $\mathrm{Cr}(\mathrm{VI})$; (ii) degradasi fenol pada sistem terpisah ( $\mathrm{pH}=2$ untuk reduksi $\mathrm{Cr}(\mathrm{VI})$ dan $\mathrm{pH}=7$ untuk degradasi fenol, $\left.\mathrm{C}_{0}=40 \mathrm{ppm}\right)$
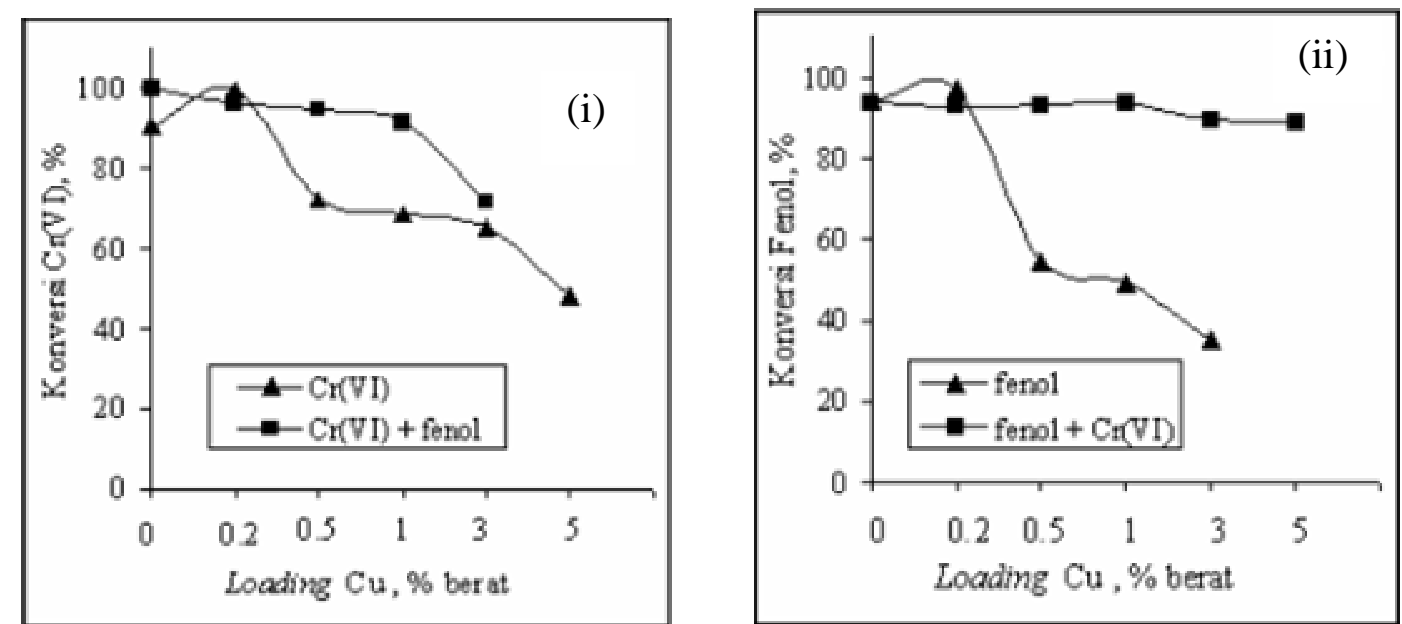

Gambar 8. Grafik perbandingan pengolahan limbah secara terpisah dan simultan, (i) reduksi $\mathrm{Cr}(\mathrm{VI})$;

(ii) degradasi fenol ( $\mathrm{t}=5 \mathrm{jam}, \mathrm{pH}=2, \mathrm{C}_{0}=40 \mathrm{ppm}$, katalis $\mathrm{CuO} / \mathrm{TiO}_{2}$ dengan prekursor $\mathrm{Cu}-\mathrm{Asetat}$ )

Fenomena berbeda terjadi pada pengolahan limbah secara simultan, seperti terlihat pada Gambar 8. Penambahan dopan $\mathrm{CuO}$ dengan komposisi $0,2 \%$ tidak menghasilkan reduksi limbah $\mathrm{Cr}(\mathrm{VI})$ maupun degradasi fenol yang optimal. Bahkan untuk degradasi fenol, penambahan $\mathrm{CuO}$ dari $0,2-1 \%$ tidak memberikan perubahan yang berarti, hal itu dapat disebabkan karena tingkat kesulitan oksidasi dari fenol, karena untuk dapat mengoksidasi fenol perlu ditempuh jalur yang begitu panjang dengan adanya pembentukan intermediet-intermediet dari senyawa fenol.

Apabila dibandingkan antara proses terpisah dengan simultan, terlihat bahwa proses simultan memiliki efisiensi pengolahan limbah yang lebih tinggi. Hal tersebut terjadi karena selain $\mathrm{CuO}$ yang berfungsi sebagai electron trapping penambahan fenol juga menyebabkan terhambatnya rekombinasi elektron-hole karena fenol berfungsi sebagai hole scavenger. Sehingga dalam proses pengolahan limbah secara simultan terdapat reaksi reduksi-oksidasi yang berjalan secara sinergis.

\section{Kesimpulan}

Dari penelitian yang dilakukan didapatkan kesimpulan, antara lain :

1. Peningkatan komposisi $\mathrm{Cu}(1-5 \%)$ pada katalis $\mathrm{CuO} / \mathrm{TiO}_{2}$ yang dipreparasi dari prekursor $\mathrm{Cu}-$ Asetat dan Cu-Nitrat memiliki pengaruh signifikan terhadap perubahan spektra absorbansi dan nilai energi band gap dari katalis $\mathrm{TiO}_{2}$. Penggunaan prekursor Cu-Nitrat menyebabkan pergeseran pita absorbansi dari katalis $\mathrm{TiO}_{2}$ ke arah sinar tampak (398-482 nm) dan menurunkan energi band gap (3,20-2,58 eV), sementara prekursor $\mathrm{Cu}$-Asetat menggeser pita absorbansi (398-430 nm) dan menurunkan energi band gap (3,20-2,81 eV).

2. Hasil karakterisasi XRD memperlihatkan kristal $\mathrm{TiO}_{2}$ Degussa P25, yaitu anatase dan rutil, tidak 
berubah signifikan terhadap penambahan dopan CuO. Sementara puncak CuO hanya muncul pada katalis $\mathrm{CuO} / \mathrm{TiO}_{2}$ yang dipreparasi dari prekursor $\mathrm{Cu}-N i t r a t$ dan $\mathrm{Cu}$-Asetat dengan ukuran kristal $\mathrm{CuO}$ dari prekursor Cu-Asetat lebih kecil dibandingkan dari prekursor Cu-Nitrat.

3. Pada proses pengolahan limbah $\mathrm{Cr}(\mathrm{VI})$ dan degradasi fenol dengan konsentrasi awal limbah 40 ppm, katalis $0,2 \% \mathrm{CuO} / \mathrm{TiO}_{2}$ yang dipreparasi dari prekursor $\mathrm{Cu}$-Asetat merupakan katalis yang memiliki aktivitas optimal. Jumlah Cr(VI) yang berhasil direduksi sebesar 99,67\% dan fenol terdegradasi sebesar $97,18 \%$.

4. Pada proses pengolahan limbah fenol dan $\mathrm{Cr}(\mathrm{VI})$ secara simultan katalis $\mathrm{TiO}_{2}$ Degussa P25 merupakan katalis yang memiliki aktivitas tertinggi. Jumlah $\mathrm{Cr}(\mathrm{VI})$ yang direduksi sebesar $100 \%$ dan jumlah fenol yang berhasil direduksi sebesar 93,81\%.

5. Secara umum kinerja katalis $0,2 \% \mathrm{CuO} / \mathrm{TiO}_{2}$ dari prekursor $\mathrm{Cu}$-Asetat merupakan katalis yang memiliki aktivitas optimal pada proses pengolahan limbah fenol dan Cr(VI), baik secara terpisah maupun simultan.

\section{Ucapan Terima Kasih}

Penulis ingin mengucapkan terima kasih kepada RUT 11 sebagai pemberi bantuan dana terhadap berlangsungnya penelitian ini.

\section{Daftar Pustaka}

Angelidis, T. N., Koutlemani, M., Poulios, (1998), "Kinetic Study of the Photocatalytic Recovery of Pt from Aqueous Solution by $\mathrm{TiO}_{2}$, in A Closed-loop Reactor”, Appl. Catal. B: Environmental, 16, 347-357.
Bokhimi, X., dan Novaro, O., (1999), “copper precursor Effect on Reducibility and Titania Phases Concentration of Sol-Gel Cu/TiO 2 Catallyst”, J. Solid State Chem., vol.144, 349-353.

Chiang, K., Amal, R., dan T. Tran, (2002), "Photocatalytic Degradation of Cyanides Using Titanium Dioxide Modified with Copper Oxide", Adv. in Environ. Res., vol.6, 471-485.

Dingwangchen, Ray, A. K., (1999), "Photocatalytic kinetics of phenol and its derivatives over UV irradiated $\mathrm{TiO}_{2}$ ”, Appl. Catal. B: Environtmental, 23:2-3:143-157.

Khalil, L.B., Mourad, W.E., Rophael, M.W., (1998), "Photocatalytic reduction of environmental pollutant $\mathrm{Cr}(\mathrm{VI})$ over some semiconductors under UV/visible light ilumination”, Appl. Catal. B: Environtmental, 17:3:267-273.

Ku, Y., Jung, I., (2001), "Photocatalytic Reduction Of $\mathrm{Cr}(\mathrm{VI})$ in Aqueous Solutions By UV Irradiation with the Presence of Titanium Dioxide”, Wat. Res., vol. 35, No.1, hal. 135-142.

Richard, WH., “Copper Compounds”, Encyclopedia of Chemistry, vol.7, hal. .505-520.

Slamet; Nasution, H.W.; Purnama, E.; Kosela, S.; Gunlazuardi, J., (2005), "Photocatalytic Reduction of $\mathrm{CO}_{2}$ on Copper-Doped Titania Catalysts Prepared by Improved-Impregnation Method”, Catal. Commun., 6 (5), 313-319.

Syakur, R., (2002), "Reduksi Limbah Logam Berat Chromium (VI) dengan Fotokatalis Serbuk $\mathrm{TiO}_{2}$ ”, Skripsi Sarjana, Jurusan TGP FTUI, Depok. 